\title{
A SELECTION OF ISSUES CONCERNING THE SACRAMENT OF THE HOLY EUCHARIST IN THE VALID CANONICAL LEGISLATION
}

Arkadiusz Mirostaw Czaja (OFM)*

\section{ABSTRACT:}

The Most Holy Eucharist commemorates the agony, death and rising from the dead of the Son of God. The Eucharist is one of the most venerable and the most blessed sacraments which Jesus Christ appointed for man. Christ Himself is contained in the sacrament. The Holy Eucharist is the source of life for the Church and it enables the Church to grow spiritually. Furthermore, the sacrament of the Eucharist constitutes the Church and determines its missionary purposes. Therefore, every Catholic should be aware of the fact he/she is obliged to take an active part in Holy Mass on Sunday and the Holy Days of Obligation, if they want to follow Jesus Christ faithfully in their life and fulfill the duties resulting from the call, in a manner corresponding to their vocation.

Key words: valid canonical legislation,

\section{INTRODUCTION}

The Eucharist is one of the most venerable and the most blessed sacraments which the Saviour appointed for man. Christ the Lord Himself is contained in the sacrament. In the Holy Sacrament of the Eucharist Christ gives Himself to us as food to take on our way to the Kingdom of God. 
Every Catholic should realize that he/she has the duty to take an active part in the Eucharist on Sunday and on the Holy Days of Obligation, if he/she wants to follow Christ faithfully in the life and perform tasks assigned to him/her responding to their vocation.

\section{GENERAL ISSUES REGARDING THE SACRAMENT OF THE BLESSED EUCHARIST}

The sacrament of the Holy Eucharist is the source of life for the entire community of the Roman Catholic Church, since Jesus Christ Himself is contained in it, He who humbled Himself to become the food for man so that we could grow spiritually ${ }^{1}$. It is also the sacrament of God's mercy towards all people and the bond of mutual love between God and man. Yet, at the same time, it is a sign of unity of all Christians worldwide $^{2}$. The name "Eucharist" derives from the Greek language and means thanksgiving".

Celebrating Holy Mass is an action of Jesus Christ and the Church; during the mass the Redeemer acting through the priest is offering Himself up in sacrifice to God the Father for the sake of all people, and is giving Himself to the faithful as Spiritual Nourishment on their way to salvation ${ }^{3}$. Receiving Holy Communion strengthens the Christian in both spiritual and physical aspects. Moreover, it makes man free from venial sins

${ }^{1}$ Cf. Gorecki, E. Title III. The Most Holy Eucharist. In: Comments to the Code of Canon Law. T. III/2. Book IV. The Sanctifying office of the Church. Part I. The Sacraments. Part II. The Other acts of divine worship. Part III. Sacred places and times/Tytut III. Najsiviętsza Eucharystia, w: Komentarz do Kodeksu Prawa Kanonicznego, T. III/2, Księga IV. Uświęcające zadania Kościota. Część I. Sakramenty. Część II. Pozostate akty kultu Bożego. Część III. Miejsca i czasy święte, Ed. J. Krukowski., Pallotinum 2011, p. 84; Mering, K. The Eucharistic life of family/Życie eucharystyczne $w$ rodziniel The monthly magazine of the Diocese of Pelplinl Miesięcznik Diecezji Pelplińskiej. III, No. 1/19 (1994), p. 56.

2 The Code of Canon Law (1983)/Kodeks Prawa Kanonicznego, can. 897; Cf. Gorecki, E. Title III. The Most Holy Eucharist. art. cit., p. 84.

${ }^{3}$ The Catechism of the Catholic Church, no 1409; Cf. Podlejski, Z. (2009). Man does not live by bread alone. Letters for the year A, B, C/Nie samym chlebem żyje cztowieka. Homilie na $\operatorname{rok} A, B, C$. Krakow, p. 152-153. 
and gives power to defeat all temptations which we must face in the entire life. It also protects us and preseves from mortal sins as well as restores and deepens the unity with Christ and the whole community of the Church ${ }^{4}$. Receiving the holy sacrament of baptism earlier is the first of substantial conditions to allow a person to receive Holy Communion.

Celebrating Holy Mass and receiving Holy Communion is the greatest form of the Eucharistic worship. Therefore the Eucharistic Sacrifice is the beginning and the purpose of various forms of worshipping God. Other forms of the worship are as follows: adoration, the Eucharistic procession, the service and Eucharistic congresses. The adoration of the Holy Sacrament of the Eucharist expresses love and devotion due to Christ contained in the Eucharist ${ }^{5}$. Adoration is aimed at establishing personal contact with Jesus Christ present in the Eucharist, enables us to thank for graces already received and gives an opportunity to make our requests personally. Adoration can be held in every church where the Host is stored. It is not allowed to make the Exposition of the Blessed Sacrament of the Eucharist while in the same temple at the same time of the day Holy Mass is being celebrated. Furthermore, at least one person must be present in the place of worship - this is a condition to the practice of Exposing the Blessed Sacrament. The Holy Sacrament must not be exposed when nobody is predicted to be present during adoration ${ }^{6}$.

The ordinary minister of the Exposition of the Blessed Sacrament must be the one who has already received the sacrament of Holy Orders. Provided that a priest or a deacon is absent, an acolyte or other extraordinary minister of Holy Communion delegated by the Ordinary of the place is allowed to perform the Rite of the Exposition. However, they cannot administer the blessing at the end of the Exposition. When the service or

${ }^{4}$ The Catechism of the Catholic Church, no 1416.

5 The Catechism of the Catholic Church, no 1418; Cf. Szczot, E. (2000). The right to the Eucharist for the faithful according to the Code of Canon Law of 1983/Prawo wiernego do Eucharystii wedtug Kodeksu Prawa Kanonicznego z 1983 roku, Lublin, p. 127.

${ }^{6}$ The Code of Canon Law, can. 942; Cf. Pawluk, T. (1986). Canon Law according to the Code of John Paul II. T. II. The People of God, teaching and sanctifying them/Prawo kanoniczne wedtug Kodeksu Jana Pawta II, T. 2, Lud Boży jego nauczanie i uświęcanie. Olsztyn, p. 397. 
adoration is about to end, after the prayer for the end of the service, they should only put the Eucharist away to the tabernacle ${ }^{7}$.

Another form of the Eucharistic worship are processions with the Holy Sacrament. It is recommended to plan the route of the Eucharistic procession to celebrate Corpus Christi as well as the routes of processions on the occasion of other important celebrations so as to include the main streets of villages or cities 8 . Processions are held during church feasts in parishes, during the time of Eucharistic congresses and in the octave of Corpus Christi. Directives on the Eucharistic procession are included in competence of the diocesan bishop who is obliged to determine legal-liturgical regulations ${ }^{9}$. By means of the Eucharistic procession participants manifest their faith in public.

Eucharistic services are the next form of worshipping God. Services are held on first Thursdays, Fridays, Saturdays and Sundays of the month, during the retreat time, periods of the missionary activity and other religious circumstances. The main aim of services is to develop incentives to promote the spirit of penance in the Christian society. Another form of public religious cult practices are Eucharistic congresses aimed at deepening the aspect of the Eucharistic mystery and at worshipping $\operatorname{God}^{10}$. A Eucharistic congress attracts plenty of Christians from all over the world.

7 The Code of Canon Law, can. 943; Cf. Hemperek, P. (1986). Part I. Sacraments. In: Comments to the Code of Canon Law of 1983. Book III. The Teaching function of the Church. Book IV. The Sanctifying office of the Church/Czessic I. Sakramenty, w: Komentarz do Kodeksu Prawa Kanonicznego z 1983 r. Ksiegga III. Nauczycielskie zadanie Kościoła. Księga IV. Uświęcające zadanie Kościota. Eds. P. Hemperek [and others], Lublin, p. 140.

${ }^{8}$ Cf. Stutkowski, Sz. (2007). The Pastoral project. In: The Church spreading the Gospel of hope. The Pastoral project of the Church in Poland for the years 2006-2010. Let us become disciples of Christl Projekt duszpasterski, w: Kościót niosący Ewangelię nadziei. Program duszpasterski Kościota Polski na lata 2006-2010. Bąźmy uczniami Chrystusa. Ed. id, Poznań 2007, s. 269.

9 The Code of Canon Law, can. 944, \$\$ 1-2; Cf. Hemperek, P. Part I. Sacraments, art. cit., p. 140.

${ }^{10}$ Cf. Sztafrowski, E. (1986). Canon Law. A textbook/Podręcznik prawa kanonicznego. T. I. Warszawa, p. 225. 


\section{THE AIM OF RESERVING HOLY COMMUNION}

Holy Communion is stored in the tabernacle for the Last Rites called Viaticum, as well as for granting Holy Communion to the sick outside Holy Mass and finally for adoration of Christ contained in the Eucharist. Receiving Holy Communion in the eleventh hour of our earthly life is of special importance for every Catholic. Therefore, on top of the above-mentioned purposes there is the need to provide a person who is ill with Holy Communion as Viaticum, which is the nourishment on the way to the eternal life ${ }^{11}$. The ordinary minister of Viaticum is a diocesan bishop, a parish priest, a parish vicar, a chaplain, a superior of the institute of the consecrated life of monastic communities and associations of the apostolic life for his subordinates and the ones dwelling in the religious house, as well as a deacon or the extraordinary minister: the acolyte and the person designated by the competent authority of the Church ${ }^{12}$.

It is the parish priest first of all who has the duty to minister Viaticum as the parish priest is the one who takes spiritual care of the faithful within the parish directly ${ }^{13}$. However, if a Christian is in danger of death, Viaticum can be given also by another priest, and when the priest is absent then a deacon or an extraordinary minister of Holy Communion is allowed to do $\mathrm{it}^{14}$. Everyone who gave Viaticum and is not a priest of the person receiving it is obliged to inform the parish priest about the service. Whenever possible Viaticum should be ministered during Holy Mass celebrated in the presence of the person who is ill, should consist of both forms and should be given along with renewal of the baptismal promises by the sick ${ }^{15}$.

11 The Catechism of the Catholic Church, no 1524; Cf. Sacrosanctum Concilium, no 22.

12 The Code of Canon Law, can. 911, \$\$ 1-2; Cf. Pastuszko, M. The Most Holy Eucharist. [can. 923-930]/ ]/Obrzędy I ceremonie sprawowania Eucharystii [kanony 923-930]. Canon Law/Prawo Kanoniczne, p. 130.

${ }^{13}$ The Code of Canon Law, can. 530, no 3.

${ }_{14}$ The Code of Canon Law, can. 911, \$2; Cf. Pastuszko, M. The Most Holy Eucharist. art. cit., p. 132 .

${ }^{15}$ The Code of Canon Law, can. 925; Cf. Glinkowski, B. (2001). The Eucharist. The Law of the Church every day/Eucharystia. Prawo Kościota na co dzień. Poznań, p. 46. 
The legislator imposes an obligation to reserve Holy Communion in cathedrals, parish churches as well as churches and chapels associated with monasteries of institutes of the consecrated life and associations of the apostolic life ${ }^{16}$. Moreover, the Ordinary of the place has the right to grant permission to store the Most Holy Sacrament of the Eucharist in other Catholic churches within his diocese. The Eucharist can also be stored in the chapel of the bishop ${ }^{17}$. In each place where the Eucharist is reserved a person should be designated to be responsible for the care of the Blessed Sacrament and Holy Mass should be celebrated in this place at least twice a month ${ }^{18}$.

The Church legislator allows to store the Host outside the church, for example in the principal oratory or monastic chapel, at night or in other justified cases. A grave cause must occur in order to take Holy Communion to another more secure place for the time of night ${ }^{19}$. The Eucharist must not be kept in flats or private houses and carrying the Eucharist around is forbidden unless some necessity urges or the diocesan bishop allows it. Then, he should provide prescripts and determine conditions as for Holy Communion to be reserved in the private house or to be carried around, even if it is not required ${ }^{20}$. The person who takes, keeps or leaves the Most Blessed Eucharist in order to desecrate it, commits sacrilege and commits a grave sin as well as must face the penalty of excommunication in very the moment of committing the offence. Dismissal from the penalty of excommunication for this criminal act is reserved exclusively to the Holy See. When such an offence is committed by a clergyman or a consecrated person, other penalties can be imposed including expulsion from the clergy and the consecrated ${ }^{21}$.

${ }^{16}$ The Code of Canon Law, can. 934, \$ 1, no 1; Cf. Glinkowski, B. The Eucharist. Law. art. cit., p. 50 .

${ }^{17}$ The Code of Canon Law, can. 934, \$1, no 2; Cf. can. 936; Glinkowski, B. The Eucharist. Law. art. cit., p. 50.

18 The Code of Canon Law, can. 934, \$ 2; Cf. Glinkowski, B. The Eucharist. Law. art. cit., p. 50 .

${ }^{19}$ The Code of Canon Law, can. 938, \$ 4; Cf. Hemperek, P. Part I. Sacraments. art. cit., p. 138.

${ }^{20}$ The Code of Canon Law, can. 935; Cf. Glinkowski, B. The Eucharist. Law. art. cit., p. 50.

${ }^{21}$ The Code of Canon Law, can. 1367. 
The Holy Sacrament is always stored in a tabernacle, which should be steadily fastened, opaque and made of solid materials. Every tabernacle must be locked in order to prevent any possibility of profanation ${ }^{22}$. The Eucharist should be reserved in one tabernacle in the Catholic church ${ }^{23}$. The tabernacle should be placed in a distinguished part and appropriately embellished, because Jesus Christ is present there. The tabernacle, where the Holy Sacrament of the Eucharist is kept, must be situated in a proper way so as to let the faithful pray in private in front of it. ${ }^{24}$. Before the tabernacle an "eternal lamp" should shine, which is a sign for those entering the temple informing them about the presence of Christ. The legislator obliges the priest who is in charge of a church or a chapel to ensure access inside at least for a few hours a day for the faithful who want to pray in private ${ }^{25}$.

\section{THE ELEMENTS REQUIRED TO CONSTITUTE A VALID SACRAMENT OF THE EUCHARIST}

Jesus Christ is a chief celebrant of Holy Mass, high priest, who acting through the ministry of the priest leads the liturgy. The Sacrament of Holy Orders received and the intention as well as applying the appropriate matter and the form are necessary for the validity of the Mass ${ }^{26}$. During liturgy of Holy Mass the priest consecrates bread and wine into the Body and Blood of Christ. As a consequence, in the person of Christ he celebrates

${ }^{22}$ The Code of Canon Law, can. 938, \$3; Cf. Dudziec, P. (1974). The rule for fireproof tabernacles. In: Legislation of the Church in Poland 1961-1970. T. II, Diocesan legislation/ Zarzadzenia $w$ sprawie ogniotrwatych tabernakulów, w: Prawodawstwo Kościota $w$ Polsce 1961-1970, T. II, Ustawodawstwo diecezjalne. Ed. T. Pieronek, Warszawa, p. 20-21.

${ }^{23}$ The Code of Canon Law, can. 938, \$ 1; Cf. Hemperek, P. Part I. Sacraments, art. cit., p. 137.

${ }^{24}$ The Code of Canon Law, can. 938, \$ 2; Cf. The Catechism of the Catholic Church, no 1183 .

${ }^{25}$ See. The Code of Canon Law, can. 937; Glinkowski, B. The Eucharist. Law. art. cit., p. 51 .

${ }^{26}$ The Code of Canon Law, can. 900, \$ 1; Cf. Glinkowski, B. The Eucharist. Law. art. cit., p. 14. 
the Eucharist and offers it to God on behalf of the entire community of the Church ${ }^{27}$.

Before instituting the Sacrament of the Eucharist Jesus Christ told Apostles to prepare paschal celebrations/the Passover meal ${ }^{28}$. Apostles, respecting Christ's command, prepared the Passover according to Jewish dietary laws. At the Passover God's Chosen Nation used wheat bread ${ }^{29}$ therefore Jesus used wheat bread for consecration during the Last Supper, unleavened bread. Hence, wheat bread is the matter necessary for the importance of the Eucharist, unleavened bread ${ }^{30}$. Using bread for the transformation is significant, because bread is a sign of the unity of all Christians - unity which the Eucharist constitutes and reflects ${ }^{31}$. Bread used for consecration must be freshly baked as well as must have the proper colour, density and taste of bread. When there are doubts concerning bread, its composition or freshness, it cannot be used for consecration ${ }^{32}$. We must be aware of the fact that Christ is present even in the smallest particle of the Host ${ }^{33}$.

During the Last Supper Christ took the cup of wine mixed with a bit of clean water, which he turned into His Blood and gave to the Apostles to drink $^{34}$. The wine used for the celebration must be fruit of the vine, natural, clean, without additives of any kind and untainted, obtained by means of natural fermentation. White wine is used mainly. However, it is possible to use red wine too. The act of pouring water into wine is the custom orig-

27 The Catechism of the Catholic Church, no 1411; Cf. Ecclesia de Eucharistia, no 28.

${ }^{28}$ Lk 22: 8.

${ }^{29} \mathrm{Wj} 34,18$.

${ }^{30}$ See. Szlaga, J.B. Biblical texts about the Eucharist/Biblijne przekazy o Eucharystii/The monthly magazine of the Diocese of Pelplin/Miesięcznik Diecezji Pelplinskiej. V, No. 3/45 (1996), p. 139.

${ }^{31}$ Ecclesia de Eucharistia, no 43.

32 The Code of Canon Law, can. 924, \$2; Cf. can. 926.

33 See. Szlaga, J.B. From the Paschal Lamb to the Eucharist. The Last Supper Mass letter of The Bishop of Pelplin AD 2006 (13 April, 2006)/Od Baranka Paschalnego do Eucharystii. Homilia Biskupa Pelplińskiego ze Mszy Świętej Wieczerzy Pańskiej. Pelplin Katedra 13 kwietnia 2006/The monthly magazine of the Diocese of Pelplin/Miesięcznik Diecezji Pelplinskiej. XV, No. 4/155 (2006), p. 404.

${ }^{34}$ Lk 22: 17-18; Cf. Mt 26: 29. 
inating from the Jewish tradition. When having a meal accompanied with wine they poured a little water into it.

The next element required for the validity of the Sacrament of the Eucharist is the form - namely the words of consecration. Transubstantiation of bread into the Body and wine into the Blood takes place by means of the Eucharistic prayer through the words of Jesus Christ and the power of the Holy Spirit acting through the ministry of the priest. The use of the species of bread and wine clearly emphasizes the Eucharistic nature of the feast. The words used by Christ during the Last Supper constitute the words of the transubstantiation which the priest celebrating Holy Mass says slowly and clearly, with special reverence ${ }^{35}$. A priest having only one of the species of the matter: bread or wine cannot begin the Mass. Furthermore, only one of the species of the matter must not be consecrated ${ }^{36}$. Apart from the matter and the form of the Eucharist one more element is required: the intention of the priest - that is the will to consecrate bread and wine into the Body and Blood of Christ. Without the intention consecration won't be made and won't result in the transubstantiation of bread and wine into the Body and Blood of the Saviour.

\section{THE TIME AND THE PLACE OF CELEBRATING HOLY MASS}

In the first centuries Christians used to gather for Holy Mass on the first day of the week in order to receive Holy Communion the day when

${ }^{35}$ At the time he was betrayed and entered willingly into his Passion, he took bread and, giving thanks, broke it, and gave it to his disciples, saying: TAKE THIS, ALL OF YOU, AND EAT OF IT: FOR THIS IS MY BODY WHICH WILL BE GIVEN UP FOR YOU. In a similar way, when supper was ended, he took the chalice and, once more giving thanks, he gave it to his disciples, saying: TAKE THIS, ALL OF YOU, AND DRINK FROM IT: FOR THIS IS THE CHALICE OF MY BLOOD, THE BLOOD OF THE NEW AND ETERNAL COVENANT, WHICH WILL BE POURED OUT FOR YOU AND FOR MANY FOR THE FORGIVENESS OF SINS. DO THIS IN MEMORY OF ME. Cf. Mt 26: 26-30; Mk 14: 22-25; Lk 22: 19-20; 1 Cor 11: 23-25.

36 The Code of Canon Law, can. 927; Cf. Hemperek, P. Part I. Sacraments. art. cit., p. 127. 
Jesus Christ rose from the dead. Later on, they gathered on other weekdays too. At present, celebrating the Mass and administering Holy Communion is held every day and at any time with some exceptions ${ }^{37}$. Good Friday is an exception, Holy Mass is not exercised on that day. On Good Thursday Holy Mass is celebrated in a cathedral in the morning, however, the Mass of the Last Supper is celebrated in the evening.

In normal conditions Holy Mass should be celebrated in a sacred place: a church, a chapel, a sanctuary and a graveyard ${ }^{38}$. The decision as for celebrating the Eucharist outside a sacred place is taken by a priest himself when he believes it is right, which means there is a reasonable cause and the location where the Eucharist is supposed to be held is a worthy place ${ }^{39}$. However, it is necessary to remember that Holy Mass must not be exercised without the corporal and there must be at least one clean altar cloth on the altar where the Eucharist is to be celebrated ${ }^{40}$. An altar is a special place in every church. It symbolizes Jesus Christ Himself and it is a meeting-place of God and man, a sign of the Sacrifice of the Cross, the Lord's table and the centre of thanksgiving during the celebration of Holy Mass. Thus, it should be situated in a central place of the chancel and ought to be visible for all participants of the Eucharist ${ }^{41}$.

\section{THE MINISTER OF THE EUCHARIST \\ AND THE MINISTER OF HOLY COMMUNION}

The minister of Holy Mass is only a priest, and so are bishops and presbyters. Among Ministers of Holy Communion ordinary and extraordinary ones can be distinguished. The ordinary minister is a person who received

${ }^{37}$ The Code of Canon Law, can. 931; Cf. Glinkowski, B. The Eucharist. Law. art. cit., p. 15.

38 The Code of Canon Law, can. 1205.

39 The Code of Canon Law, can. 932, \$ 1; Cf. Hemperek, P. Part I. Sacraments. art. cit., p. 134.

${ }^{40}$ The Code of Canon Law, can. 932, \$ 2; Cf. Glinkowski, B. The Eucharist. Law. art. cit., p. 16.

${ }^{41}$ The Catechism of the Catholic Church, no 1383. 
Holy Oders. Therefore, a bishop, a presbyter and a deacon are such ordinary ministers ${ }^{42}$. Apart from the ordinary minister of Holy Communion the Church legislator defines the extraordinary ones. Such extraordinary ministers are acolytes and other members of the faithful designated for this purpose by the competent authority of the Church for the period of one year. Another special group entitled to do it are the catechists.

The priest as the ordinary minister of Holy Communion is obliged to carry it to the sick, the elderly and the disabled. If there is no ordinary minister of Holy Communion or there are obstacles due to illness, advanced age or other pastoral duties, and when great numbers of the faithful want to receive Holy Communion, or for any other serious reason, the extraordinary minister is allowed to distribute Holy Communion ${ }^{43}$. The extraordinary minister can carry the Host to the faithful, also as Holy Viaticum, only when the priest cannot do it himself. The extraordinary minister is to help the priest to distribute Holy Communion within the area of the parish. The extraordinary minister must be designated by the diocesan bishop to perform this honourable function. However, he should first undergo proper formation in order to be able to become a reliable minister of Holy Communion.

An acolyte is a special extraordinary minister of Holy Communion and he has priority over the one designated to be on the duty for the time of a year with possibility to prolong it for the following year. A permanent acolyte may become a man, the Catholic who is twenty five years or over, and has appropriate predispositions to perform the liturgical service, has adequate theological knowledge as well as spiritual formation. Moreover, also women may perform the function of the extraordinary ministers of Holy Communion as designated for the time of a year, under the same conditions as those determined for men who want to do the service. The number of extraordinary ministers designated by the diocesan bishop for the particular parish should be adequate to satisfy the pastoral needs there.

${ }^{42}$ The Code of Canon Law, can. 910, \$ 1; Cf. Glinkowski, B. The Eucharist. Law. art. cit., p. 34 .

${ }^{43}$ The Code of Canon Law, can. 910, \$ 2; Cf. Glinkowski, B. The Eucharist. Law. art. cit., p. 34. 


\section{THE OBLIGATION FOR THE CATHOLIC TO PARTICIPATE IN HOLY MASS}

The applicable Code of Canon Law from 1983 accepted the catalogue of the Holy Days of Obligation from the previous Code of Canon Law from 1917 without any changes. In the Roman Catholic Church the Holy Days of Obligation are the following: the Nativity of our Lord Jesus Christ, the Epiphany, the Ascension, the Body and Blood of Christ, Holy Mary the Mother of God, her Immaculate Conception, her Assumption, Saint Joseph, Saint Peter and Paul the Apostles and All Saints ${ }^{44}$.

Observing the precepts of ceremonial nature of a holy day includes such elements as: participation in the Eucharist and the prayer in private, the time for relaxation as well as the concern for family. These elements have a significant influence on the comprehensive development of man. Fostering the culture of celebrating a holy day, one cannot focus on religious arguments only, but it is necessary to emphasize also legal and social rights. They should be treated as the common good of the entire Roman Catholic Church and the cultural value. Their cultural importance has both individual as well as social dimension.

Participation of Catholics in the Eucharist is among essential factors of God's worship, since Holy Mass always has the nature of social activity of the Roman Catholic Church. They are present in it as its members, and the Eucharist constitutes the good of the entire $\mathrm{Church}^{45}$. One should be aware of the fact that every Eucharist, particularly on Sunday and the Holy Day of Obligation, is of greatest importance for building the unity with God and for educating Catholics to participate in religious celebrations on these special days properly ${ }^{46}$.According to Canon Law, the Catholic is obliged to participate in the Eucharistic Sacrifice on such days ${ }^{47}$. It fos-

${ }^{44}$ The Code of Canon Law, can. 1246, \$ 1; Cf. Pawluk, T. Canon Law. art. cit., p. 475.

${ }^{45}$ Cf. Woźniak, Z. I will sing the Lord on His holy day/W dzień Pański-śpiewać Panu. Colloqua Theologica Ottoniania. No. 1 (2012), p. 168.

${ }^{46}$ Ecclesia de Eucharistia, no 32; Cf. no 40-41; Mokrzycki, B. Why Sunday?/ Dlaczego niedziela? Collectanea Theologica. No. 4/48 (1978), p. 129-135.

${ }^{47}$ CCDDS, Celebrazione della parola e precetto domenicale. (03 February, 1987). Notitiae. No. 23 (1987), p. 169. 
ters piety of Catholics as well as is the endless source of the experience of $\operatorname{God}^{48}$. The Eucharist on a holy day has the same significance as Holy Mass celebrated any other day of the week. The unique nature of the Eucharist on Sunday results from the fact that Sunday is the day when Christ rose from the dead, therefore it is a special and exceptional day for the Chris$\operatorname{tian}^{49}$. It imposes the duty of participation in the Eucharistic liturgy on the entire community of the Church. Presence at the Eucharist includes the good will above all, which means having an appropriate intention to venerate God. If the Catholic does not have such an intention, his presence cannot be regarded as participation in Holy Mass ${ }^{50}$. Apart from an appropriate attitude one's personal reflection is necessary. The awareness that holy actions take place on the altar is required.

The Catholic is obliged to participate in the Mass unles a grave cause occurs which prevents him from fulfilling this obligation. The above-mentioned duty is universal as the Eucharistic Sacrifice is an important event for the Catholic on a holy day ${ }^{51}$. Holy Mass is the source and the sacrament of life as well as an anticipation of our resurrection from the dead. Regular participation in the Eucharist on a holy day is important for spiritual life of the faithful ${ }^{52}$.

${ }^{48}$ Cf. Jeż, A. (2002). Striving toward full haromony of life. Holiness. The gift and the task. In: Into the third millennium. Pastoral comments to documents of the Second Polish Plenary Synod/Dązyć ku petni życia. Świętość. Dar i zadanie, w: W trzecie tysiąclecie. Komentarz pastoralny do dokumentów II Polskiego Synodu Plenarnego. Ed. W. Lechnowicz, Tarnów, p. 184.

${ }^{49}$ Cf. Kalbarczyk, A. Celebrating a homily in the context of celebrating the Eucharist and Sundayl Celebracja homilii w kontekście celebracji Eucharystii i niedzieli. Colloquia Theologica Ottoniania, No. 1 (2012), p. 74.

${ }^{50}$ Cf. Olejnik S. (1989). Moral theology. Vol.4. The Gift. The Call. The Response. Basic foundations of the Christian life/Teologia moralna. T. 4. Dar. Wezwanie. Odpowiedź. Podstawowe ukierunkowanie życia chrześcijańskiego. Warszawa, p. 205.

${ }^{51}$ Cf. Skotnicki, J. Sudany/Niedziela. In: Catholicism A-Z/Katolicyzm A-Z. Ed. Z. Pawlak, Łódź, p. 296-297.

${ }^{52}$ Cf. Margański, B. (2002). To live by Liturgy. Liturgy after the Second Vatican Synod. In: Into the third millennium. Pastoral comments to documents of the Second Polish Plenary Synod/Żyć i kierować sie „duchem liturgii”. Liturgia Kościota po Soborze Watykańskim II, w: W trzecie tysiaclecie. Komentarz pastoralny do dokumentów II Polskiego Synodu Plenarnego. Ed. W. Lechnowicz, Tarnów, p. 156. 
The Catholic fulfills the duty of participation in the Mass celebrated according to the rites of the Catholic Church on the holy day or the day before in the evening ${ }^{53}$. In this way the Church legislator allows people who cannot do it on Sunday and the Holy Day of Obligation to participate in the Eucharist ${ }^{54}$. Participation in Holy Mass cannot be perceived as a legal duty only but it should be regarded, above all, as the response to the love of God, who reveals Himself fully in the Eucharist. When motivating Catholics to participate in the Mass, one should not avoid emphasizing the fact that participation in the Eucharistic Sacrifice is not only an individual problem of the faithful as negligence in performing this obligation is directed against God, the Church and family ${ }^{55}$.

If it is not possible to participate ino the Eucharist exercised by the Catholic priest, the faithful can take part in the Mass celebrated by the priest of the Orthodox Church, since this Church has the holy sacraments ${ }^{56}$. The Catholic is not obliged to participate one more time in the Eucharist celebrated in the Roman Catholic Church, if he/she participated in the Mass in the Orthodox Church in special situations, once and for a serious reason ${ }^{57}$.

In the places where it is not possible to participate in the Eucharist, even the one celebrated by the priest of the Orthodox Church, it is rec-

${ }^{53}$ The Code of Canon Law, can. 1248, \$ 1; Cf. Glinkowski, B. The Eucharist. Law. art. cit., p. 21.

${ }^{54}$ Cf. Sztafrowski, E. Canon Law. A textbook. art. cit., p. 266.

55 The Catechism of the Catholic Church. No. 2181; Cf. Wielebski, T. (2011). The Church in Poland and the concern about Sunday as the time for unity and communion. In: The Church as home for us. The Church as home and the school of communnion. The Pastoral programme of the Church in Poland for the years 2010-2013. Year 2011/2012/Troska Kosiciota $w$ Polsce o niedziele jako czas budowania komunii, w: Kościót naszym domem. Kościót domem i szkota komunii. Program duszpasterski Kościota w Polsce na lata 2010-2013, R. 2011/2012. p. 273.

${ }^{56}$ Cf. The Code of Canon Law, can. 844, \$2; Krukowski, J. (2011). Part III. Sacred places and sacred times. In: Comments to the Code of Canon Law. T III/2. Book IV. The Sanctifying office of the Church. Part I. The Sacraments. Part II. The Other acts of divine worship. Part III. Sacred places and times/Część III. Miejsca i czasy święte, w: Komentarz do Kodeksu Prawa Kanonicznego, T. III/2. Księga IV. Uświęcające zadanie Kościoła. Część I. Sakramenty. Część II. Pozostate akty kultu Bożego. Część III. Miejsca i czasy święte. Eds. Id., Pallotinum, p. 469.

${ }^{57}$ Cf. Pawluk, T. Canon Law. art. cit., p. 476-477. 
ommended to participate in the Liturgy of the Word, run by the person designated by the authority of the Church, appropriately prepared to do $\mathrm{it}^{58}$. It is possible to receive Holy Communion during this service ${ }^{59}$. When there is not even such a possibility to participate in the service on Sunday and the Holy Day of Obligation, it is recommended to pray individually. In such cases, prayer in the family circle is also recommended, together with a few families in particular ${ }^{60}$. When one is not able to participate in the Eucharist, it is not required to find any replacement, because Canon Law does not enforce any other obigation by way of the substitution, only another prayer is recommended ${ }^{61}$.

People who in no way can directly participate in Holy Mass, especially the disabled, the sick and the elderly, can participate spiritually in the Eucharist broadcast by the media ${ }^{62}$. If they do not have access to the media, they are encouraged to get spiritually united with liturgy of the Mass through their own prayer. The Catholic who does not have any obstacles so as to take part in the Eucharistic Sacrifice in a temple, and watches it via the media, does not fulfill the duty of Christian participation in Holy Mass.

${ }^{58}$ Cf. Martín de Agar, J. T. Part III. Sacred places and sacred times. In: Comments to the Code of Canon Law. General legislation and particular singular decrees of the Catholic Church. Fundamental administrative acts of the Polish religious law. Eds. P. Majer/Czesśc III. Miejsca i czasy święte, w: Kodeks Prawa Kanonicznego. Komentarz. Powszechne i partykularne ustawodawstwo Kościota katolickiego. Podstawowe akty polskiego prawa wyznaniowego. Kraków, Pallotinum. p. 924-925.

${ }^{59}$ CCDDS, Directorium Christi Ecclesia. (02 June, 1988). Notitiae. No. 24 (1988), p. 366-378.

${ }^{60}$ The Code of Canon Law, can. 1248, $\$ 2$; Cf. Krukowski, J. Part III. Sacred places and times. art. cit., p. 470-471.

${ }^{61}$ Cf. Martín de Agar, J. T. Part III. Sacred places and times art. cit., p. 924.

${ }^{62}$ Cf. Bakalarz J. (1986). Part III. Sacred places and sacred times. Commentary to the Code of Canon Law of 1983. Vol.3. Book III. The Teaching function of the Church. Book IV. The Sanctifying office of the Church/Czesśc. III. Miejsca i czasy święte, w: Komentarz do Kodeksu Prawa Kanonicznego z 1983 r., T. 3, Księga III. Nauczycielskie zadanie Kościota. Księga IV. Uświęcające zadanie Kościota. Eds. P. Hemperek [et al.], Lublin, p. 420. 


\section{CONCLUSION}

The Holy Sacrifice of the Mass commemorates the agony, death and rising from the dead of the Son of God. It is from the Eucharist that the Church lives and grows, because Christ is contained in the Eucharist, Christ, who humbled Himself to become the food for the faithful so that we could grow spiritually. Thus, the Sacrament of the Eucharist constitutes the Church and determines its missionary purposes. The aim of the article is to shed some light on the subject matter in order to encourage readers to further deepen the theological-canonical knowledge about the Eucharist.

\section{REFERENCES:}

Bakalarz, J. (1986). Part III. Sacred places and sacred times. In: Comments to the Code of Canon Law of 1983. T.3. Book III. The Teaching function of the Church. Book IV. The Sanctifying office of the Church/Częśc. III. Miejsca i czasy siwięte, w: Komentarz do Kodeksu Prawa Kanonicznego z 1983 r., T. 3, Ksiega III. Nauczycielskie zadanie Kościota. Księga IV. Uświęcające zadanie Kościota. Eds. P. Hemperek [and others], Lublin, pp. 375-429.

Dudziec, P. (1974). The rule for fireproof tabernacles. In: Legislation of the Church in Poland 1961-1970. T. II, Diocesan legislation/Zarzadzenia w sprawie ogniotrwatych tabernakulów, w: Prawodawstwo Kościoła w Polsce 1961-1970, T. II, Ustawodawstwo diecezjalne. Ed. T. Pieronek, Warszawa, p. 20-21.

Glinkowski, B. (2001). The Eucharist. The Law of the Church every day/Eucharystia. Prawo Kościota na co dzień. Poznan.

Gorecki, E. Title III. The Most Holy Eucharist. In: Comments to the Code of Canon Law. T. III/2. Book IV. The Sanctifying office of the Church. Part I. The Sacraments. Part II. The Other acts of divine worship. Part III. Sacred places and times/Tytut III. Najświętsza Eucharystia, w: Komentarz do Kodeksu Prawa Kanonicznego, T. III/2, Księga IV. Uświęcające zadania Kościota. Część I. Sakramenty. Część II. Pozostate akty kultu Bożego. Część III. Miejsca i czasy święte. Ed. J. Krukowski. Pallotinum 2011, p. 83-140.

Hemperek, P. (1986). Part I. Sacraments. In: Comments to the Code of Canon Law of 1983. Book III. The Teaching function of the Church. Book IV. The Sanctifying office of the Church/Czes'ic I. Sakramenty, w: Komentarz do Kodeksu Pra- 
wa Kanonicznego z 1983 r. Księga III. Nauczycielskie zadanie Kościoła. Księga IV. Uświęcające zadanie Kościota. Eds. P. Hemperek [and others], Lublin, p. 61-212.

Jez, A. (2002). Striving toward full haromony of life. Holiness. The gift and the task. In: Into the third millennium. Pastoral comments to documents of the Second Polish Plenary Synod/Dązyć ku petni życia. Świętość. Dar i zadanie, w: W trzecie tysiaclecie. Komentarz pastoralny do dokumentów II Polskiego Synodu Plenarnego Ed. W. Lechnowicz, Tarnów, p. 177-197.

Kalbarczyk, A. Celebrating a homily in the context of celebrating the Eucharist and Sunday/Celebracja homilii w kontekście celebracji Eucharystii i niedzieli. Colloquia Theologica Ottoniania, No. 1 (2012), p. 63-80.

Krukowski, J. (2011). Part III. Sacred places and sacred times. In: Comments to the Code of Canon Law. T III/2. Book IV. The Sanctifying office of the Church. Part I. The Sacraments. Part II. The Other acts of divine worship. Part III. Sacred places and times/Część III. Miejsca i czasy święte, w: Komentarz do Kodeksu Prawa Kanonicznego, T. III/2. Księga IV. Uświęcające zadanie Kościota. Część I. Sakramenty. Część II. Pozostate akty kultu Bożego. Część III. Miejsca i czasy święte. Eds. Id., Pallotinum, p. 423-476.

Marganski, B. (2002). To live by Liturgy. Liturgy after the Second Vatican Synod. In: Into the third millennium. Pastoral comments to documents of the Second Polish Plenary SynodlŻyć i kierować się „duchem liturgii”. Liturgia Kościota po Soborze Watykansskim II, w: W trzecie tysiaclecie. Komentarz pastoralny do dokumentów II Polskiego Synodu Plenarnego. Ed. W. Lechnowicz, Tarnów, p. 154-165.

Martin de Agar, J.T. (2011). Part III. Sacred places and sacred times. In: Comments to the Code of Canon Law. General legislation and particular singular decrees of the Catholic Church. Fundamental administrative acts of the Polish religious law. Eds. P. Majer/Część III. Miejsca i czasy święte, w: Kodeks Prawa Kanonicznego. Komentarz. Powszechne i partykularne ustawodawstwo Kościoła katolickiego. Podstawowe akty polskiego prawa wyznaniowego. Kraków, Pallotinum. p. 898-927.

Mering, K. The Eucharistic life of family/ Życie eucharystyczne $w$ rodzinie/The monthly magazine of the Diocese of Pelplin/Miesięcznik Diecezji Pelplinskiej. III, No. 1/19 (1994), p. 54-66.

Mokrzycki, B. Why Sunday?/Dlaczego niedziela? Collectanea Theologica. No. 4/48 (1978), p. 129-135.

Olejnik, S. (1989). Moral theology. T.4. The Gift. The Call. The Response. Basic foundations of the Christian life/Teologia moralna. T. 4. Dar. Wezwanie. Odpowiedź. Podstawowe ukierunkowanie życia chrześcijańskiego Warszawa. 
Pastuszko, M. The Most Holy Eucharist. [can. 923-930]/Obrzędy I ceremonie sprawowania Eucharystii [kanony 923-930]. Canon Law/Prawo Kanoniczne, No. 1-2/36 (1993), p. 69-130.

Pawluk, T. (1986). Canon Law according to the Code of John Paul II. T. II. The People of God, teaching and sanctifying them/Prawo kanoniczne wedtug Kodeksu Jana Pawta II, T. II, Lud Boży jego nauczanie i uświęcanie. Olsztyn.

Podlejski, Z. (2009). Man does not live by bread alone. Letters for the year A, B, C/Nie samym chlebem żyje cztowieka. Homilie na rok $A, B, C$, Krakow, p. 152-153.

Skotnicki, J. (1989). Sudany/Niedziela. In: Catholicism A-Z/Katolicyzm A-Z. Ed. Z. Pawlak, Łódź, p. 295-297.

Stułkowski, Sz. (2007). The Pastoral project. In: The Church spreading the Gospel of hope. The Pastoral project of the Church in Poland for the years 2006-2010. Let us become disciples of Christ/Projekt duszpasterski, w: Kościót niosacy Ewangelie nadziei. Program duszpasterski Kościota Polski na lata 2006-2010. Bądźmy uczniami Chrystusa. Ed. id, Poznan 2007, p. 265-270.

Szczot, E. (2000). The right to the Eucharist for the faithful according to the Code of Canon Law of 1983/Prawo wiernego do Eucharystii wedtug Kodeksu Prawa Kanonicznego z 1983 roku, Lublin.

Szlaga, J.B. Biblical texts about the Eucharist/Biblijne przekazy o Eucharystii/The monthly magazine of the Diocese of Pelplin/Miesięcznik Diecezji Pelplinskiej. V, No. 3/45 (1996), p. 132-143.

Szlaga, J.B. From the Paschal Lamb to the Eucharist. The Last Supper Mass letter of The Bishop of Pelplin AD 2006 (13 April, 2006)/Od Baranka Paschalnego do Eucharystii. Homilia Biskupa Pelplińskiego ze Mszy Świętej Wieczerzy Pańskiej. Pelplin Katedra 13 kwietnia 2006/The monthly magazine of the Diocese of Pelplin/Miesięcznik Diecezji Pelplinskiej. XV, No. 4/155 (2006), p. 401-405.

Sztafrowski, E. (1986). Canon Law. A textbook/Podręcznik prawa kanonicznego. T. I. Warszawa.

Wielebski, T. (2011). The Church in Poland and the concern about Sunday as the time for unity and communion. In: The Church as home for us. The Church as home and the school of communnion. The Pastoral programme of the Church in Poland for the years 2010-2013. Year 2011/2012/Troska Kościota w Polsce o niedziele jako czas budowania komunii, w: Kościót naszym domem. Kościót domem $i$ szkota komunii. Program duszpasterski Kościota $w$ Polsce na lata 2010-2013, R. 2011/2012. Ed. S. Stułkowski, Saint Wojciech - Poznań, p. 261-285.

Wozniak, Z. I will sing the Lord on His holy day/W dzień Pański - śpiewać Panu, Colloqua Theologica Ottoniania. No. 1 (2012), p. 167-188. 